\begin{tabular}{|c|c|c|c|}
\hline \multirow{2}{*}{$\begin{array}{c}\text { LARUS } \\
\text { Hrvatska akademija } \\
\text { znanosti i umjetnosti }\end{array}$} & 55 & $\begin{array}{c}\text { 34-41 str. } \\
\text { 2 tablice, } 1 \text { slika }\end{array}$ & Zagreb 2020. \\
\cline { 2 - 4 } & \multicolumn{3}{|c|}{$\begin{array}{c}\text { Primljeno 5.9.2020. } \\
\text { Prihvaćeno od Razreda za prirodne znanosti HAZU 28.11.2020. }\end{array}$} \\
\hline
\end{tabular}

UDK 636.082.471(497.571)

Original scientific paper Izvorni znanstveni članak DOI: https://dx.doi.org/10.21857/yq32oh2729

\title{
THE BREEDING BIRDS OF PALUD, ISTRIA
}

\author{
Ptice gnjezdarice Paluda, Istra
}

\author{
Louie Thomas Taylor ${ }^{1}$, Sanjin Hadžalić, Katarina Horvat, Luka lelas \\ ${ }^{1}$ Ulica Vladimira Gortana 27, Rovinj 52210, Croatia
}

\begin{abstract}
During the spring of 2020, bird surveys were conducted in the ornithological reserve Palud. There were 35 breeding species registered. The most numerous species were the Eurasian Blackcap Sylvia atricapilla, the Common Nightingale Luscinia megarhynchos, the Common Blackbird Turdus merula, and the Eastern Subalpine Warbler Sylvia cantillans. A vulnerable breeder of Croatia, the Black-winged Stilt Himantopus himantopus, and a scarce breeder, the Common Shelduck Tadorna tadorna, were also recorded as breeding species.
\end{abstract}

Keywords: breeding birds, Mediterranean wetland, Istria

\section{INTRODUCTION}

The Mediterranean wetlands are important habitats for the foraging, resting and breeding of many birds (Liondos et al. 2014). Almost one half of the world's natural wetlands disappeared in the course of the last century due to anthropogenic activities, whereas others were variously affected (Shine \& KLEMm 1999). In Croatia, there are few large wetlands in the Mediterranean area, so that smaller wetlands provide important habitats for the breeding, migrating and wintering birds. These wetlands have not been sufficiently studied in Croatia. One of these wetlands is the marsh Palud. No qualitative ornithological data were found for Palud, just a historical list of the recorded species (Lukač \& Stelкo 2016). The aim of this paper is to provide an updated qualitative list of the breeding bird species of Palud, and to provide a rough estimate of the number of the breeding pairs.

e-mail: louie040@hotmail.com 


\section{MATERIAL AND METHODS}

The study was conducted at the special ornithological reserve Palud - Palù (later in text Palud), located between the towns of Rovinj and Bale, from March to July 2020 (Fig 1.). The position of the study area is approximately $45^{\circ} 01^{\prime}-45^{\circ} 02^{\prime}$ N, $13^{\circ} 41^{\prime}-13^{\circ} 42^{\prime}$ E. Palud was protected in 2001 as a special ornithological reserve "Palud - Palù" for its brackish marsh that provides suitable habitats for the breeding, migrating and wintering birds. It is a natural marsh, connected to the sea by a canal. The area of the reserve is $2.26 \mathrm{~km}^{2}$. The marsh takes up $9 \%$ of the area and is surrounded by a Mediterranean, thermophilic forest with downy oak Quercus pubescens scrubs that takes up $64 \%$ of the area. The rest of the area $(27 \%)$ is covered by agricultural fields (BARDi et al. 2016).

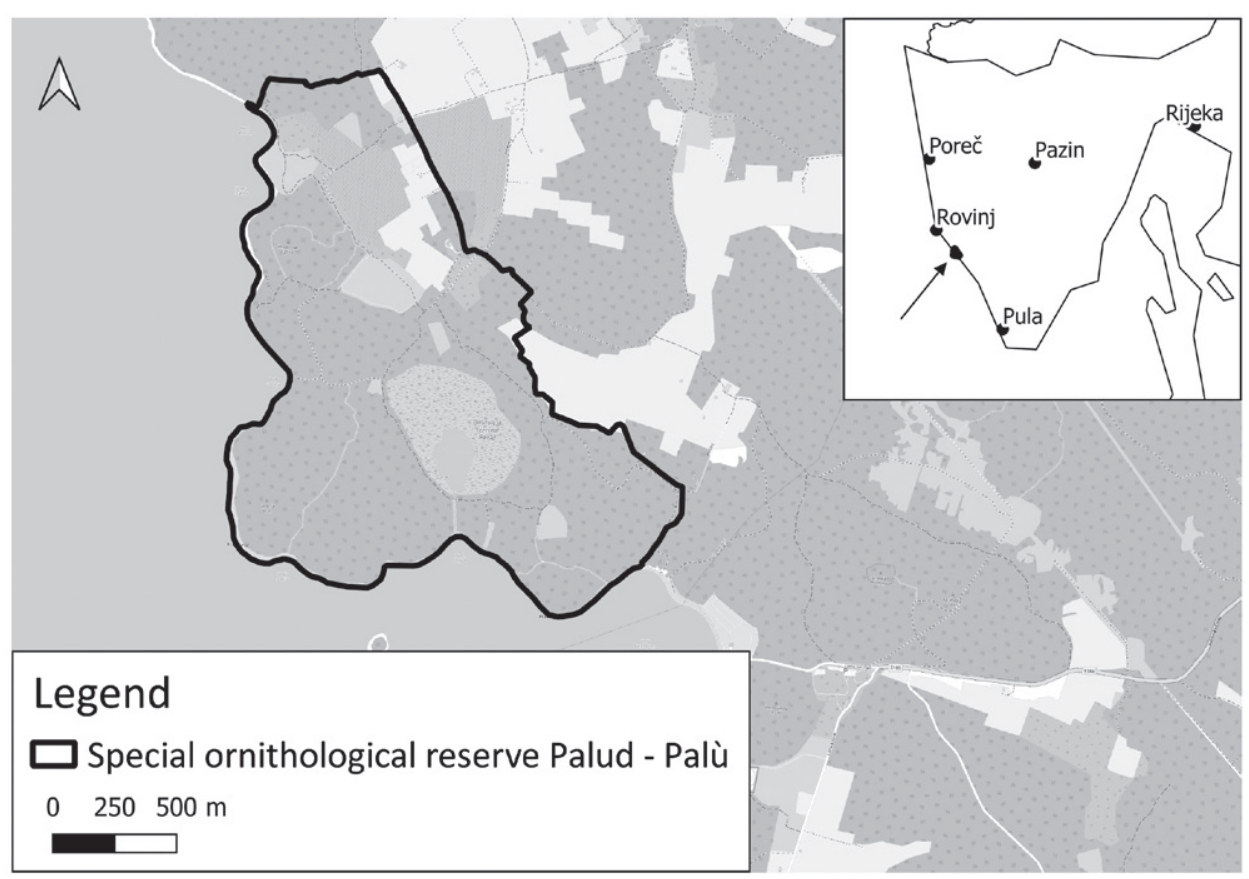

Figure 1. Location of the special ornithological reserve Palud - Palù (Source: Open street map and (C) EuroGeographics for the administrative boundaries)

Slika 1. Položaj ornitološkog rezervata Palud - Palù (izvor: Open street map $i$ () EuroGeographics for the administrative boundaries) 
The point count methodology was carried out by estimating the number of the breeding pairs using the auditory detection of singing males. Where auditory detection was not possible, birds were recorded visually. The point count methodology with three-band radius $(>100 \mathrm{~m}, 30-100 \mathrm{~m}$, and $<30 \mathrm{~m})$ was carried out for obtaining data during the breeding season (GREGory et al. 2004). Twenty-two point counts were placed at the study site, each at least $250 \mathrm{~m}$ away from the closest one. Point counts were performed early in the morning - between sunrise and 9:30 AM. Two counts were completed for each point during the breeding season. The time for sampling at each point was six minutes. The first minute was meant for birds to settle to the presence of the researcher, while birds were counted during the following 5 minutes only (Bibby et al. 1992, Gregory et al. 2004). The number of the recorded birds in the radius of 30 meters was too low to estimate the density; hence, we calculated the average number of birds in the radius of 30 meters for the most common species. The rough number of some breeding pairs was estimated by the number of singing males.

The bird nest counting method was conducted for the abundance of the breeding birds near houses and agricultural habitats. Besides nest counting, characteristic behaviours, such as returning to the nest, displaying, and callings were used to determine the number of the breeding pairs in the study area. This was done for the Hooded Crow Corvus cornix, the Eurasian Magpie Pica pica, and the Barn Swallow Hirundo rustica.

Individuals of wildfowl populations were counted before and during the breeding season. Paired individuals were monitored as described by KRALJ et al. (1998). The entire water surface was surveyed from the embankments, using a point from which the most part of the marsh was visible.

Playback method was used after sunset on five points for the Scops Owl Otus scops and the European Nightjar Caprimulgus europaeus, and on two points for the Water Rail Rallus aquaticus. The points were at least $500 \mathrm{~m}$ apart, and the birds' distance and direction from the researcher was recorded to minimize the possibility of double counting. Lures were played in succession from a portable speaker, lasting a minute followed by a minute of silence. These sound lure cycles were repeated three times per species.

Accidental bird observations were also recorded while moving between points during point counts and throughout the area, with the aim of spotting scarce or skulking species.

The Common Pheasant Phasianus colchicus, although frequently recorded in Palud, was omitted from the study due to the study area being surrounded by hunting grounds and not knowing if hunters release them into the wild. 


\section{RESULTS}

A total of 35 breeding species were recorded in the ornithological reserve Palud. There were 17 breeding species recorded in the forest, 16 breeding species recorded in agricultural fields, and only 6 species recorded in the marsh and its reed bed.

The most numerous bird species in the 30-meter radius of the counting points were the Common Nightingale Luscinia megarhynchos with 0.27 birds per point, the Eurasian Blackcap Sylvia atricapilla with 0.18 birds per point, and the Eastern Subalpine Warbler Sylvia cantillans with 0.14 birds per point. The estimated number of birds in the 30-meter radius is shown in Table 1.

Table 1. Estimated number of birds in the 30-meter radius in Palud using the point count method.

Tablica 1. Procijenjene brojnost ptica u radiusu od 30 metra na Paludu koristeći metodu prebrojavanja u točki

\begin{tabular}{|l|c|}
\hline Species & No. of birds per point \\
\hline Columba palumbus & 0.09 \\
\hline Luscinia megarhynchos & 0.27 \\
\hline Turdus merula & 0.09 \\
\hline Sylvia atricapilla & 0.18 \\
\hline Sylvia cantillans & 0.14 \\
\hline Parus major & 0.07 \\
\hline Cyanistes caeruleus & 0.05 \\
\hline Coccothraustes coccothraustes & 0.09 \\
\hline
\end{tabular}

The most numerous species recorded were the Eurasian Blackcap (43 breeding pairs), the Common Nightingale (37 pairs), the Eastern Subalpine Warbler (22 pairs), and the Common Blackbird Turdus merula (20 pairs). The roughly estimated number of the breeding pairs for all the recorded species is shown in Table 2. The most numerous breeding species of the marsh were the Black-winged Stilt Himantopus himantopus and the Mallard Anas platyrhynchos with 6 and 5 breeding pairs, respectively. The most numerous breeding non-passerines in the forest were the Turtle Dove Streptopelia turtur with 12 pairs, and the Scops Owl with 5 pairs. The estimated numbers of the breeding pairs in Palud are shown in Table 2. 
Table 2. Estimated number of breeding pairs per bird species in Palud using the numbers of singing males, counting bird nest, counting wildfowl, sound luring, and accidental observations.

Tablica 2. Procijenjena brojnost parova ptica na Paludu putem prebrojavanja pjevajućih mužjaka, gnijezda, ptica močvarica, zvučnog vaba i slučajnih opažanja

\begin{tabular}{|c|c|c|}
\hline Species & Number of breeding pairs & Method \\
\hline Tadorna tadorna & 1 & Counting wildfowl \\
\hline Anas platyrhynchos & 5 & Counting wildfowl \\
\hline Tachybaptus ruficollis & 3 & Counting wildfowl \\
\hline Accipiter nisus & 1 & Accidental observations \\
\hline Rallus aquaticus & 3 & Playback method \\
\hline Fulica atra & 4 & Counting wildfowl \\
\hline Himantopus himantopus & 6 & Counting wildfowl \\
\hline Columba palumbus & 3 & Number of singing males \\
\hline Streptopelia decaocto & 1 & Accidental observations \\
\hline Streptopelia turtur & 12 & Number of singing males \\
\hline Otus scops & 5 & Playback method \\
\hline Caprimulgus europaeus & 2 & Playback method \\
\hline Upupa epops & 2 & Number of singing males \\
\hline Jynx torquilla & 2 & Accidental observations \\
\hline Lullula arborea & 3 & Number of singing males \\
\hline Hirundo rustica & 3 & Counting bird nest \\
\hline Luscinia megarhynchos & 37 & Number of singing males \\
\hline Turdus merula & 20 & Number of singing males \\
\hline Sylvia atricapilla & 43 & Number of singing males \\
\hline Sylvia melanocephala & 2 & Accidental observations \\
\hline Sylvia cantillans & 22 & Number of singing males \\
\hline Parus major & 8 & Number of singing males \\
\hline Cyanistes caeruleus & 5 & Number of singing males \\
\hline Aegithalos caudatus & 3 & Accidental observations \\
\hline Pica pica & 2 & Counting bird nest \\
\hline Garrulus glandarius & 3 & Accidental observations \\
\hline Corvus cornix & 1 & Counting bird nest \\
\hline Oriolus oriolus & 3 & Accidental observations \\
\hline Passer domesticus & 4 & Accidental observations \\
\hline Fringilla coelebs & 11 & Number of singing males \\
\hline Chloris chloris & 1 & Number of singing males \\
\hline
\end{tabular}




\begin{tabular}{|l|c|c|}
\hline Species & Number of breeding pairs & Method \\
\hline Serinus serinus & 2 & Number of singing males \\
\hline $\begin{array}{l}\text { Coccothraustes } \\
\text { Coccothraustes }\end{array}$ & 7 & Accidental observations \\
\hline Emberiza cirlus & 3 & Number of singing males \\
\hline Emberiza calanda & 4 & Number of singing males \\
\hline
\end{tabular}

Some species were found using the area for foraging, though they did not breed in it, with breeding areas in the close vicinity of Palud. The Common Buzzard Buteo buteo was seen foraging near the agricultural fields, whilst the Yellowlegged Gull Larus michahellis and the Common Tern Sterna hirundo breed on the islands off the shore of Palud and were observed foraging in the marsh. The postnatal dispersion of the Long-eared Owl Asio otus, the Green Woodpecker Picus viridis, the Great Spotted Woodpecker Dendrocopos major, the White Wagtail Motacilla alba, and the Red-backed Shrike Lanius collurio was also observed, and the species left the area shortly after.

\section{DISCUSSION}

Different types of habitats in the ornithological reserve Palud provide suitable breeding sites for different arrays of species. A total of 35 species were recorded breeding in the ornithological reserve Palud. The largest array of species was recorded in the forest surrounding the marsh (49\% of species) and around the agricultural fields ( $46 \%$ of species). The lowest number of species was recorded in the marsh and its reed bed (17\% of species); out of those, two species were notable - the Black-winged Stilt and the Common Shelduck Tadorna tadorna.

The Black-winged Stilt is a Vulnerable breeder of Croatia, with an estimated breeding population of 45-80 pairs (TuTiš et al. 2013). It was first recorded breeding in Palud in 2018 (TAYlor 2018), but they did not breed there successfully in 2019. Their breeding was observed to be dependent to the water level of the marsh. In 2019, the water level in the marsh raised due to heavy rains, which caused the nests to be flooded. The number of six pairs might be underestimated due to the limited visibility of the marsh.

The Common Shelduck started breeding in Croatia in 2016 (Stumberger 2016). Today, it is a scarce breeder on a few sites. They started breeding in Palud in 2019 (TAYLOR 2019). Both 2016 and 2019 were successful breeding seasons, while in 2020, three juveniles were spotted in early June.

The highest number of birds was recorded in the forest in the close vicinity of the marsh and in the transition between the forest and agricultural fields, which might be due to the edge effect (Batary et al. 2014). 
We found five new breeding birds for Palud compared to the work done by Luкас̌ \& Sтецко (2016): the already mentioned Black-winged Stilts and Common Shelducks, and three more species: the Eurasian Sparrowhawk Accipiter nisus, the Eurasian Wryneck Jynx torquilla, and the Common Wood Pigeon Columba palumbus. The Common Wood Pigeon is an extremely rare breeder in the Mediterranean part of Croatia (LuKAČ 2011, ĆiKović 2013).

In this paper, we provided an updated list of the breeding bird species and their roughly estimated number of the breeding pairs. The Mediterranean marshes also provide a suitable habitat for the migrating and wintering birds (especially Charadriiformes and Anseriformes), and are important stopover places (Mediterranean Wetlands Observatory 2012). More research should be done during the migration and wintering seasons, in order to gain a better insight into the whole ornithofauna of Palud. Moreover, additional research should be done on vulnerable and scarce breeding species and their breeding success in Palud.

\section{References}

Bardi, A., Papini, P., Quaglino, E., Biondi, E., Topić, J., Milović, M., Pandža, M., Kaligarič, M., Oriolo, G., Roland, V., Batina, A., Kirin, T. (2016): Karta prirodnih i poluprirodnih ne-šumskih kopnenih i slatkovodnih staništa Republike Hrvatske. AGRISTUDIO s.r.l., TEMI S.r.l., TIMESIS S.r.l., HAOP.

Batary, P., Fronczek, S., Normann, C., Scherber, C., Tscharntke, T. (2014): How do edge effect and tree species diversity change bird diversity and avian nest survival in Germany's largest deciduous forest? Forest Ecology and Management 319: 44-50.

Bibby, C. J., Burgess, N. D., Hill, D. A. (1992): Bird Census Techniques. Academic Press Ltd., London.

Ćíović, D. (2013): Golub grivnjaš Columba palumbus. Pg 119 in: KRALJ, J., Barišić, S., Tutıš, V., Ćiković, D. (eds): Atlas selidbe ptica Hrvatske, Croatian Bird Migration Atlas. Hrvatska akademija znanosti i umjetnosti, Zavod za ornitologiju, Zagreb.

Gregory, R.D., Gibbons, D.W., Donald, P.F. (2004): Bird census and survey techniques. pp 17-56. In: Sutherland W.J., Newton I. et Green R.E. (eds.): Bird Ecology and Conservation; a Handbook of Techniques. Oxford University Press, Oxford

KralJ, J., Radović, D., Tutiš, V. (1998): Numbers and seasonal activity of Anatide at Draganić fishponds in NW Croatia. Vogelwelt 119: 21-29

Liordos, V., Pergantis, F., Perganti, I. Roussopoulos, Y. (2014): Long-term population trends reveal increasing importance of a Mediterranean wetland complex (Messolonghi lagoons, Greece) for wintering waterbirds. Zoological Studies 53: 12

LuKAč, G. (2011): Atlas ptica Nacionalnog parka Paklenica. Javna ustanova Nacionalni park Paklenica, Starigrad-Paklenica.

Lukač, G., Stelko, R. (2016): Atlas ptica Istre. Javna ustanova Natura Histrica, Pula.

Mediterranean Wetlands Observatory (2012): Biodiversity - Status and trends of species in Mediterranean wetlands. Thematic collection, issue 1. Tour du Valat, France. $52 \mathrm{pp}$. 
Shine, C. And Klemm. C (1999): Wetlands, Water and the Law. Using law to advance wetland conservation and wise use. IUCN, Gland, Switzerland, Cambridge, UK and Bonn, Germany. 330 pp.

Stumberger, B. (2016): Rezultati brojanja ptica močvarica i grabljivica u najvažnijim močvarama otoka Paga. Larus 51: 66-72.

TAYLOR, L. (2018): New breeding site of Black-winged stilts Himantopus himantopus in Croatia. Larus 53: 41-42.

TAYLOR, L. (2019): New breeding site of the Shelduck Tadorna tadorna in Croatia. Larus 54: 56.

Tutiš, V., Kralu, J., Radović, D., Ćiković, D., Barišıć, S. (ur.) (2013): Crvena knjiga ptica Hrvatske. Ministarstvo zaštite okoliša i prirode, Državni zavod za zaštitu prirode, Zagreb, 258 pp.

\section{SAŽETAK}

Tijekom proljeća 2020. godine provedeno je istraživanje ornitofaune u ornitološkom rezervatu Palud. Zabilježeno je 35 gnijezdećih vrsta ptica. Najbrojnije vrste su crnokapa grmuša Sylvia atricapilla, slavuj Luscinia megarhynchos, kos Turdus merula i bjelobrka grmuša Sylvia cantillans. Osjetljiva gnjezdarica Hrvatske, vlastelica Himantopus himantopus i malobrojna gnjezdarica Hrvatske, utva Tadorna tadorna zabilježene su kao gnijezdeće vrste. Potvrđeno je i gniježđenje kopca Accipiter nisus, vijoglava Jynx torquilla i goluba grivnjaša Columba palumbus koji do sada nisu bili zabilježeni na ovom području. 